\title{
Study of Statistical Analysis of Indices Based Rainfall Trends in Haridwar District of Uttarakhand, India
}

\author{
Avadhesh Kumar Koshal ${ }^{1 *}$ and Anamika Jain ${ }^{2}$ \\ ${ }^{1}$ Professor and Head, Faculty of Science, Motherhood University, Roorkee, India \\ ${ }^{2}$ Research Scholar, Faculty of Science, Motherhood University, Roorkee, India \\ *Corresponding Author: Avadhesh Kumar Koshal, Professor and Head, Faculty of \\ Science, Motherhood University, Roorkee, India.
}

Received: April 22, 2021

Published: May 06, 2021

(C) All rights are reserved by Avadhesh Kumar Koshal and Anamika Jain.

\section{Abstract}

The Haridwar belong to Western Himalayan Region with geographical coordinates are 29.948 deg latitude, 78.160 deg longitude. The trend analysis of rainfall pattern in Haridwar is studied through time series analysis of rainfall for a long period of 20 years. The Kharif crops production is dependent on this rainfall. The average annual rainfall of region during $1999-2018$ is $1051 \mathrm{~mm}$. and south west monsoon rainfall $925.9 \mathrm{~mm}$ observed.. The annual rainfall in year 2007 showing the highest positive rainfall anomaly (2.31) while the other years show rainfall below normal with 2009 Showing the lowest negative rainfall deviation (-2.03). and the South west (1999 to 2018) rainfall of Haridwar District in year 2018 showing the highest positive rainfall anomaly (2.15) while the other years show rainfall below normal with 2009 Showing the lowest negative rainfall deviation (-2.05). The $R^{2}$ value -1.408 means that only -140.8 percent variations is observed in twenty years. The maximum South west rainfall recoded 1564 mm in year 2008 and lowest rainfall recoded $439 \mathrm{~mm}$ in year 2001. The annual rainfall highest SIAP value 2.31 is observed in year 2007 whereas highest negative value -2.03 is observed in year 2009. The South-west rainfall highest SIAP value 2.15 observed in year 2018 whereas lowest SIAP value -2.05 observed in year 2009. On the basis, the future forecast of rainfall for a period of ten years from 2019 to 2030 has been observed a negative trend for the coming years. In future, expected annual rainfall may be more in year 2030 observed 1024.9 $\mathrm{mm}$ in the district.

In future, expected annual rainfall may be less in year 2030 observed $1025 \mathrm{~mm}$ in the District. The south west rainfall in the year 2030; expected rainfall may be $922.8 \mathrm{~mm}$. The trends are showing increasing trend pattern from year 2019 to 2030 . The trend analysis gives the scenario of current to expected future situation. Water is a vital component for agricultural crops and in abnormal period crops are irrigated by available source viz. tube well, submersible, canal, irrigation channels and other sources. The statistical analysis of annual and south west rainfall of the study area will help to better water management.

Today rainfall is not regular fashion so farmers are not more dependent much more on rainfall. The source of irrigation, mechanization and knowledge of current situation of weather and climate change related pattern and adaptation of technology is maintain to crops yield trend.

Keywords: Anomaly; Annual Rainfall; Indices; South - West Rainfall; SIAP

\section{Introduction}

Rainfall is an important vital parameter for climatic phenomenon. It gives direct affect on agricultural production. It is the main source for river and domestic water use for agriculture in the Haridwar district having plain topography, leading to great variation in rainfall spatially and temporally. The rainfall pattern is not 
as previous pattern. Now the rainfall pattern change suddenly to disturb livelihood and biodiversity. As Crozier [1] noted, the key drivers for the successful management of risk must be an awareness of threat, a sense of responsibility plus a belief that the threat can be managed or at least reduced. Alatise and Ikumawoyi [2] was concluded that the most favourable method is the rainfall anomaly index (RAI) as it provides the greatest quantity of information about the frequency and intensity of drought in the area under study. The comparison of three methods for meteorological evaluation of droughts, i.e. Palmer drought index (PDI), Bhalme- Mooley drought index (BMDI), and rainfall anomaly index (RAI) in the area of Nebraska (USA) and that the precipitation is the dominant drought-occurrence factor. Consequently, simple methods based on rainfall analysis only, can be considered to be as good as very complex drought indices Oladipo [3]. Recently Guhathakurtha and Rajeevan (2008) constructed monthly, seasonal and annual rainfall time series of 36 meteorological subdivisions of India and India as one unit using the monthly rainfall data for the period 1901-2003 with fixed network of 1476 rain gauge stations and later updated by Gughathakurta., et al. (2015). They found a very good agreement between all-India summer monsoon rainfall series constructed by them and IITM rainfall data series. The correlation between these two series is 0.97. Gogumalla., et al. [4] observed the monthly trend tests show that July rainfall is increasing whereas the December rainfall is decreasing which could be due to the seasonal shift. The start of change in the rainfall trend for the above mentioned districts is observed with distinct difference from 2009 onwards. Koshal and Kumar [5] observed trend analysis in XLSTAT 2014.6.02 ver. observed trend of rainfall, the $\mathrm{R}^{2}$ value 0.018 means that only 1.8 percent variation is observed in hundred years. The coefficient of skewness has been computed as -0.06 for annual rainfall indicates a negative trend or going to decline pattern.

Shanu and Jahangeer [6] study of determine the best-fit distribution of the annual series of rainfall data for the period of 1991-2002 of 13 districts of Uttarakhand. Weibull distribution performed the best with $46 \%$ of the total district, while the second best distribution was Chi squared (2P) and log-Pearson. Pranuthi, G. and Tripathi, S. K. [7] observed and bias corrected daily data was tested for their significance at $95 \%$ probability of occurrence employing various statistical methods such as correlation coefficient, mean bias error, normalized mean squared error, and $\mathrm{Z}$ and $\mathrm{F}$ statistical tests. Many studies are available on the observed trends and variability of rainfall and also extreme rainfall events, but all the studies are based on past 100 years or more data and also the recent years are not included (Malik., et al. 2019; Guhathakurta., et al. 2015; Guhathakurta., et al. 2011; Guhathakurta and Rajeevan, 2008 etc.). Rupali S. Ahire and Vikrant Nikam [8] observed in the Haridwar district is subjected to frequent flickering of annual rainfall. During the first five decades, the decadal average rainfall is found to be nearly same. However, anomalous behavior in annual rainfall is observed for post-1950 periods. The trend of rainfall was increasing from 1950 to 1980, whereas the last two decades of the twentieth century witnessed a sharp decrease in rainfall.

The present study was undertaken with the objective to assess the rainfall trends pattern and indices based study to understanding of current changing scenario of the Haridwar district.

\section{Study area}

Uttarakhand is a hilly state was established in year 2000 as the $27^{\text {th }}$ State of India, it is on the southern slope of the Himalaya range. The Haridwar belong to Western Himalayan Region with geographical coordinates are 29.948 deg latitude, 78.160 deg longitude. The geographical area is 2360 in $\mathrm{km}^{2}$ and 26.86 percent covered with forest $[9,10]$. The Haridwar is situated at the foothills of the Himalayas and have a plain topography. The annual mean rainfall in Haridwar is about $2136.7 \mathrm{~mm}$. The district is $288 \mathrm{~m}$ above sea level and climate is temperate. In winter, there is much less rainfall in Haridwār than in summer. The summer the temperature in Haridwar varies from $35^{\circ} \mathrm{C}$ to $45^{\circ} \mathrm{C}$. The Tropical forests such as Sal and Shisham and other tree species Khair, Semal, Kanju, Sissoo and Haldu. Bushes and shrubs are also found in this region [11].

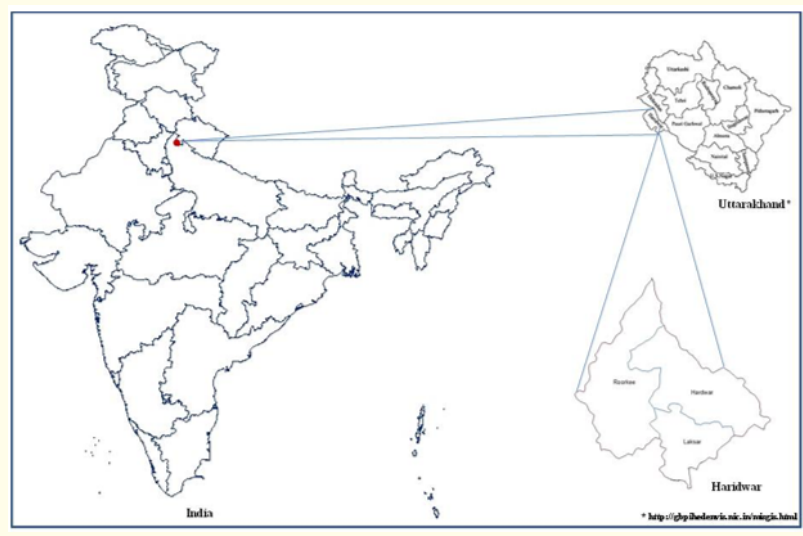

Figure 1: Study area. 


\section{Materials}

The present study is based on secondary sources of time series data of rainfall. The rainfall data (annual and monthly) rainfall of Uttarakhand state and Haridwar district for continuous 20 years 2000-20 data were obtained from IMD, New Delhi and the meteorological data tool of website IWP (2015), (http://www.indiawaterportal.org/met_data/).

\section{Methodology}

The rainfall data (annual and south west rainfall) collected and arranged in the MS Excel. The different type of statistical data analysis viz. Mean (M), Standard Deviation (SD), Coefficient of Variation (CV), Correlation of Coefficient $\left(\mathrm{R}^{2}\right)$ and Trend Analysis to given important scenario of change pattern of time series data. The rainfall indices are used for analysis of data.

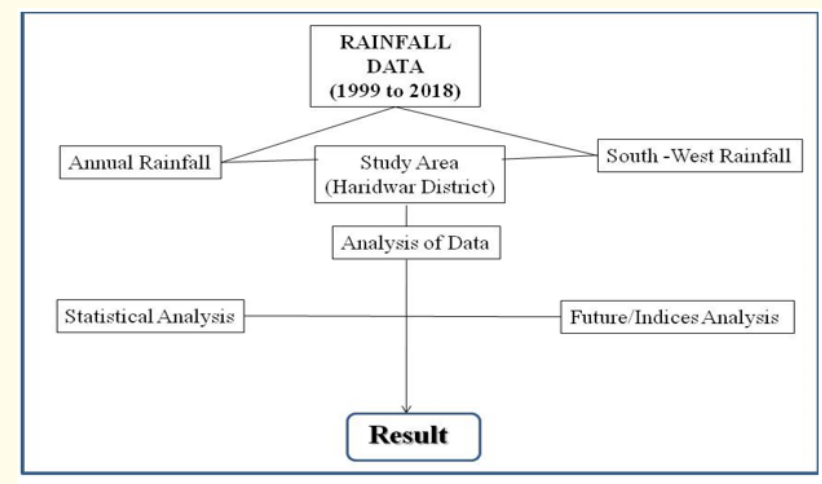

Figure 2: Methodology.

Time series analysis of the annual and South-west rainfall values were used to illustrate the trend in the behaviour of rainfall and in estimating seasonal variation. Linear regression analysis was also employed using Microsoft Excel statistical tool as it has proved effective in investigating trends in many climatic time series $[12,13]$. One of the important indices standardized anomalies was evaluated.

Several statistics are applied to monthly rainfall series such as Mean, Variance, Standard Deviation and Coefficient of Variation (CV).

For identifying the trend in the rainfall data, the statistical analysis of linear regression was used. The descriptive statistical analyses are;
Mean is the arithmetic average of a set of values or distribution and represents the average of the data set.

$\operatorname{Mean}(\overline{\mathrm{x}})=\frac{\sum \mathrm{x}}{\mathrm{N}}$

Where $\mathrm{x}$ is the rainfall data and $\mathrm{N}=$ Number of years

The Standard deviation (STD) is measure of the dispersion of a set of data from its mean.

$\operatorname{STD}=\frac{\sqrt{\sum(\mathrm{x}-\overline{\mathrm{x}})^{2}}}{\mathrm{~N}}$

The Coefficient of Variation is a normalized measure of dispersion of a probability distribution which is defined as the ratio of the standard deviation $\sigma$ to the mean $\overline{\mathrm{x}}$.

$$
\mathrm{CV}=\frac{\sigma}{\overline{\mathrm{x}}} \mathrm{x} 100
$$

The Skewness is a measure of the asymmetry of the probability distribution. The skewness value can be positive or negative, or even undefined. It is a dimensionless quantity.

$$
\text { Skewness }=\frac{\text { Mean }- \text { Mode }}{\text { Standard deviation }}
$$

Rainfall deviation from normal was calculated as:

Rainfall deviation $=($ Actual rainfall - Normal rainfall $) /$ Normal rainfall $\times 100$

The lowest value of the rainfall deviation is $-100 \%$, reflecting the occurrence of zero rainfall and the uppermost value cannot be defined. If the actual rainfall is twice the amount of normal rainfall, the rainfall deviation is $100 \%$ and the actual rainfall is thrice the amount of normal, the rainfall deviation is $200 \%$ and so on.

Standardized anomalies, also referred to as normalized anomalies, are calculated by dividing anomalies by the climatological standard deviation. $=\frac{(\mathrm{x}-\overline{\mathrm{x}})}{\text { STD }}$

Where $\mathrm{x}$ is the annual rainfall totals, $\overline{\mathrm{x}}$ is the mean of the entire series and STD is the standard deviation from the mean of the series.

In the present study, the indies are used for variation of rainfall data analysis for Haridwar was analysed on the basis of monthly and yearly dataset of 20 years (1999-2018) in terms of indices namely, Rainfall deviation and Standard Index of Annual Precipitation (SIAP). 
Standard index of annual precipitation (SIAP)

The values of Standard Index of Annual Precipitation (SIAP) can be computed by using equation:

$\operatorname{SIAP}=\left(\mathrm{P}_{\mathrm{i}}-\overline{\mathrm{P}}\right) / \mathrm{PSD}$

Where $\mathrm{Pi}=$ annual rainfall in $\mathrm{i}^{\text {th }}$ year; $\overline{\mathrm{P}}=$ average rainfall; and PSD = standard deviation observed for rainfall during study period. The trend of drought and wet years can be as certained Khalili [14] on following basis (Table 1).

\begin{tabular}{|l|c|}
\hline Classification & SIAP Value \\
\hline Extremely wet & 0.84 or more \\
\hline Wet & 0.52 to 0.84 \\
\hline Normal & -0.52 to 0.52 \\
\hline Drought & -0.52 to -0.84 \\
\hline Extreme drought - & 0.84 or less \\
\hline
\end{tabular}

Table 1: Standard Index of Annual Precipitation (SIAP) Value.

\section{Classification SIAP value}

The rainfall in India is widely variable with respect to time and different regions. The study of precipitation trends is critically important for a country like ours whose food security and economy are almost completely dependent on the felicitous availability of water. The trend analysis of rainfall pattern in Haridwar is studied through time series analysis of rainfall for a long period of 20 years. The statistical analysis of the data relating with rainfall pattern during the period from 1999-2018 has been done by procuring the data from Open Government Data Platforms. The annual rainfall highest SIAP value 2.31 is observed in year 2007 whereas highest negative value -2.03 is observed in year 2009 . The South-west rainfall highest SIAP value 2.15 observed in year 2018 whereas lowest SIAP value -2.05 observed in year 2009 .

The present paper is targeted towards analyzing the trend of rainfall for the state of Haridwar comparison of this trend with other district has been done and average annual rainfall has been indexed for inter and intra state comparison.

Trend in district rainfall

Figure 5 shows the trends in district annual and South west rainfall. It can be seen that June rainfall has shown significant increasing trend in the district Chamoli and Rudraprayag while no district has shown any significant decreasing trend. Therefore, the hydro-meteorological studies with an inherent assumption of stationary should be carried out carefully over the study area. This study may be helpful for better water resources planning and management over the district. Due to plain area available in the district Haridwar Anthropogenic activity and industrialization is also the major cause of rainfall trend fluctuation.

\section{Result and Discussion}

The annual rainfall data series during the period 1999 to 2018 are analysis using time series analysis. The result shows that over Haridwar District. The Annual rainfall and South-west rainfall or monsoon season covered almost district in June to September months. It is a most dominant session of the cyclic rainfall. The Kharif crops production is dependent on this rainfall. The average annual rainfall of region during 1999-2018 is $1051 \mathrm{~mm}$. and south west monsoon rainfall $925.9 \mathrm{~mm}$ observed. The maximum annual rainfall recoded $1633 \mathrm{~mm}$ in year 2008 and lowest rainfall recoded $533 \mathrm{~mm}$ in year 2001. The maximum South west rainfall recoded $1564 \mathrm{~mm}$ in year 2008 and lowest rainfall recoded $439 \mathrm{~mm}$ in year 2001 (Table 4).

\section{Standardized anomalies of annual rainfall}

Table 2 depicts the computed annual mean rainfall and standardized anomalies within the year under consideration (1999 to 2018) over Haridwar District. Figure 3 shows the standardized rainfall deviations viz; 2001, 2004, 2006-08, 2012, 2014, and 201718 are years with above average rainfall with 2007 showing the highest positive rainfall anomaly (2.31) while the other years show rainfall below normal with 2009 Showing the lowest negative rainfall deviation $(-2.03)$.

The South west (1999 to 2018) rainfall of Haridwar District. Figure 4 and Table 3 shows the standardized rainfall deviations viz; 2001,2002, 2004, 2006-09, 2012, 2014, and 2017-18 are years with above average rainfall with 2018 showing the highest positive rainfall anomaly (2.15) while the other years show rainfall below normal with 2009 Showing the lowest negative rainfall deviation $(-2.05)$. 


\begin{tabular}{|c|c|c|c|c|c|c|c|c|}
\hline $\begin{array}{l}\text { Sl. } \\
\text { No. }\end{array}$ & Year & $\begin{array}{c}\text { Annual } \\
\text { Rainfall } \\
\text { (mm) }\end{array}$ & $\begin{array}{c}\text { Standardized } \\
\text { Rainfall Anomaly } \\
\text { (Annual) }\end{array}$ & $\begin{array}{l}\text { SIAP } \\
\text { Value }\end{array}$ & $\begin{array}{c}\text { Rainfall } \\
\text { Deviation }\end{array}$ & $\begin{array}{l}\text { Departure from } \\
\text { Average Rainfall }\end{array}$ & $\begin{array}{c}\text { Cumulative } \\
\text { Departure from } \\
\text { average rainfall }\end{array}$ & $\begin{array}{c}\text { Trend of } \\
\text { Rainfall } \\
\text { (mm) }\end{array}$ \\
\hline 1 & 1999 & 1108.3 & -0.30 & 0.21 & 3.2 & 23.7 & -24 & 1111.0 \\
\hline 2 & 2000 & 752 & 0.69 & 0.85 & 12.8 & 126.6 & 103 & 1108.2 \\
\hline 3 & 2001 & 532 & 0.19 & -0.43 & -6.5 & -81.0 & 22 & 1105.5 \\
\hline 4 & 2002 & 603 & -0.18 & -0.23 & -3.4 & -47.4 & -26 & 1102.7 \\
\hline 5 & 2003 & 1281 & 1.15 & 1.28 & 19.3 & 196.2 & 171 & 1099.9 \\
\hline 6 & 2004 & 589 & -1.04 & -0.83 & -12.5 & -144.6 & 26 & 1097.1 \\
\hline 7 & 2005 & 1369 & 0.78 & 0.75 & 11.3 & 110.5 & 136 & 1094.3 \\
\hline 8 & 2006 & 509 & 0.39 & 0.72 & 10.9 & 106.4 & 243 & 1091.6 \\
\hline 9 & 2007 & 1417 & 1.90 & 2.31 & 34.9 & 364.1 & 607 & 1088.8 \\
\hline 10 & 2008 & 1633 & 0.04 & -0.38 & -5.8 & -73.1 & 534 & 1086.0 \\
\hline 11 & 2009 & 893 & -2.05 & -2.03 & -30.7 & -340.0 & 194 & 1083.2 \\
\hline 12 & 2010 & 1441 & -0.18 & -0.73 & -11.0 & -128.4 & 65 & 1080.5 \\
\hline 13 & 2011 & 1106 & 0.24 & 0.20 & 3.0 & 21.2 & 87 & 1077.7 \\
\hline 14 & 2012 & 821 & -0.95 & -1.56 & -23.5 & -263.4 & -177 & 1074.9 \\
\hline 15 & 2013 & 1465 & 0.13 & 0.38 & 5.7 & 50.6 & -126 & 1072.1 \\
\hline 16 & 2014 & 1036 & -0.82 & -0.24 & -3.6 & -49.0 & -175 & 1069.3 \\
\hline 17 & 2015 & 1019 & -0.89 & -0.34 & -5.1 & -65.7 & -241 & 1066.6 \\
\hline 18 & 2016 & 1104 & 0.68 & 0.19 & 2.8 & 19.6 & -221 & 1063.8 \\
\hline 19 & 2017 & 1056 & 0.20 & -0.11 & -1.7 & -28.8 & -250 & 1061.0 \\
\hline 20 & 2018 & 1287.5 & 2.15 & 1.32 & 19.9 & 202.9 & -47 & 1058.2 \\
\hline
\end{tabular}

Table 2: Average Annual rainfall, Standardized rainfall anomaly and its departure and cumulative departure from average rainfall of Haridwar (1999-2018).

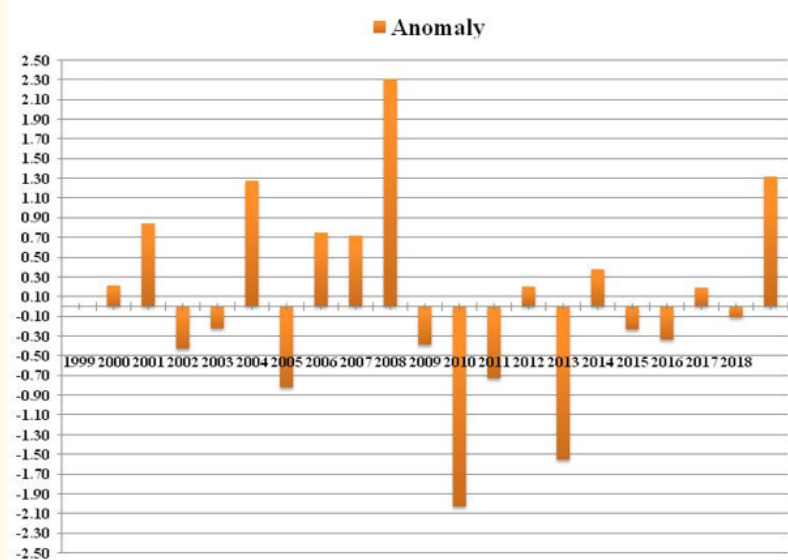

Figure 3: Standardized annual rainfall anomaly of Haridwar from 1999-2018.

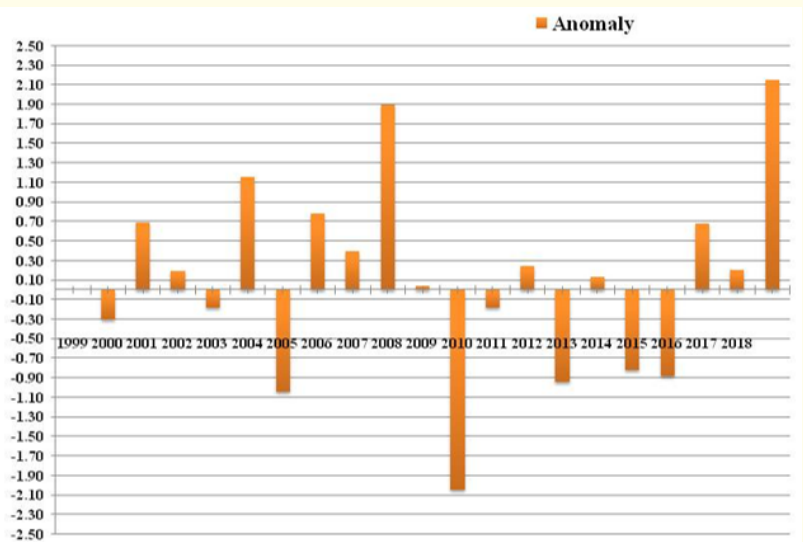

Figure 4: Standardized South west rainfall anomaly of Haridwar from 1999-2018. 


\begin{tabular}{|c|c|c|c|c|c|c|c|c|}
\hline $\begin{array}{l}\text { Sl. } \\
\text { No. }\end{array}$ & Year & $\begin{array}{c}\text { Annual } \\
\text { Rainfall } \\
\text { (mm) }\end{array}$ & $\begin{array}{c}\text { Standardized } \\
\text { Rainfall Anomaly } \\
\text { (Annual) }\end{array}$ & $\begin{array}{c}\text { SIAP } \\
\text { Value }\end{array}$ & $\begin{array}{c}\text { Rainfall } \\
\text { Deviation }\end{array}$ & $\begin{array}{c}\text { Departure } \\
\text { from Average } \\
\text { Rainfall }\end{array}$ & $\begin{array}{c}\text { Cumulative } \\
\text { Departure from } \\
\text { average rainfall }\end{array}$ & $\begin{array}{c}\text { Trend of } \\
\text { Rainfall } \\
\text { (mm) }\end{array}$ \\
\hline 1 & 1999 & 850 & 0.21 & -0.30 & -5.1 & -75.9 & 75.9 & 908.0 \\
\hline 2 & 2000 & 653 & 0.85 & 0.69 & 11.8 & -273.1 & -197.2 & 908.5 \\
\hline 3 & 2001 & 439 & -0.43 & 0.19 & 3.3 & -487.3 & -684.6 & 908.9 \\
\hline 4 & 2002 & 509 & -0.23 & -0.18 & -3.1 & -417.2 & -1101.8 & 909.4 \\
\hline 5 & 2003 & 1072 & 1.28 & 1.15 & 19.6 & 146.3 & -955.5 & 909.9 \\
\hline 6 & 2004 & 477 & -0.83 & -1.04 & -17.8 & -448.9 & -1404.4 & 910.4 \\
\hline 7 & 2005 & 1322 & 0.75 & 0.78 & 13.3 & 396.1 & -1008.3 & 910.9 \\
\hline 8 & 2006 & 509 & 0.72 & 0.39 & 6.7 & -417.2 & -1425.5 & 911.3 \\
\hline 9 & 2007 & 1394 & 2.31 & 1.90 & 32.3 & 468.5 & -957.0 & 911.8 \\
\hline 10 & 2008 & 1564 & -0.38 & 0.04 & 0.7 & 638.1 & -318.9 & 912.3 \\
\hline 11 & 2009 & 862 & -2.03 & -2.05 & -35.0 & -63.7 & -382.6 & 912.8 \\
\hline 12 & 2010 & 1331 & -0.73 & -0.18 & -3.1 & 404.6 & 22.0 & 913.3 \\
\hline 13 & 2011 & 948 & 0.20 & 0.24 & 4.1 & 21.9 & 43.9 & 913.7 \\
\hline 14 & 2012 & 752 & -1.56 & -0.95 & -16.1 & -174.2 & -130.3 & 914.2 \\
\hline 15 & 2013 & 1154 & 0.38 & 0.13 & 2.3 & 227.6 & 97.3 & 914.7 \\
\hline 16 & 2014 & 771 & -0.24 & -0.82 & -13.9 & -154.6 & -57.3 & 915.2 \\
\hline 17 & 2015 & 761 & -0.34 & -0.89 & -15.1 & -164.9 & -222.2 & 915.6 \\
\hline 18 & 2016 & 1000 & 0.19 & 0.68 & 11.6 & 74.3 & -147.9 & 916.1 \\
\hline 19 & 2017 & 927 & -0.11 & 0.20 & 3.5 & 1.3 & -146.6 & 916.6 \\
\hline 20 & 2018 & 1224 & 1.32 & 2.15 & 36.6 & 298.4 & 151.8 & 917.1 \\
\hline
\end{tabular}

Table 3: Average South west rainfall, Standardized rainfall anomaly and its departure and cumulative departure from South west rainfall of Haridwar (1999-2018).

Rainfall departure and cumulative departure of annual rainfall

The departure and cumulative departure from annual rainfall for the study area has been depicted in table 2 . The trend of annual departure from the computed value of annual rainfall (Table 2) reveals that;

- Years showing annual positive departure with respect to annual rainfall were 1999-2000, 2003, 2005-07, 2011, 2013, 2016 and 2018. The positive trend of rainfall shows the favourable conditions for recharge. The maximum positive departure value 364.1 was observed in year 2007 .

- Years showing annual negative departure with respect to annual rainfall were 2001-2, 2004, 2008-10, 2012, 2014-15 and 2017. The negative trend of rainfall shows the unfavourable conditions for recharge. The maximum negative departure value -340 was observed in year 2009 .
- Years showing negative cumulative departure from annual rainfall were observed in a twenty years data 2010 to 2018 and positive annual cumulative departure from rainfall was observed 1999 to 2009. The annual cumulative departure of annual rainfall was maximum positive value 607 observed in years 2007 but negative value -250 was observed in year 2017.

Rainfall departure and cumulative departure of South-west rainfall

The departure and cumulative departure from South-west rainfall (Table 3) for the study area has been depicted in table 3 . The trend of annual departure from the computed value of South-west rainfall reveals that;

- Years showing positive departure with respect to South -west rainfall was 2003, 2005, 2007-08, 2010-11, 2013 and 2016- 
18. The positive trend of rainfall shows the favourable conditions for recharge. The lowest positive departure value 1.3 was observed in year 2017 and maximum value 638.1 was observed in year 2008.

- Years showing annual negative departure with respect to annual rainfall were 1999, 2000-02, 2004, 2006, 2009, 2012, 2014-15. The negative trend of rainfall shows the unfavourable conditions for recharge. The maximum negative departure value -487.3 was observed in year 2001 . The minimum negative departure value -63.7 was observed in year 2009 .

- Years showing negative cumulative departure from annual rainfall were observed in a twenty years data 2000-09, 2012 and 2014-17 and positive annual cumulative departure from rainfall was observed 1999, 2010-11, 2013 and 2018. The annual cumulative departure of annual rainfall was maximum positive value 151.8 observed in years 2018 but maximum negative value -1425.5 was observed in year 2006 and minimum value -57.3 was observed in year 2014 .

\begin{tabular}{|l|c|c|}
\hline \multirow{2}{*}{ Statistical parameters } & \multicolumn{2}{|c|}{ Computed value } \\
\cline { 2 - 3 } & $\begin{array}{c}\text { Annual Rainfall } \\
\text { (mm) }\end{array}$ & $\begin{array}{c}\text { South-west } \\
\text { Rainfall (mm) }\end{array}$ \\
\hline Mean & $1051 \mathrm{~mm}$ & $925.9 \mathrm{~mm}$ \\
\hline Min & $509 \mathrm{~mm}$ & $439 \mathrm{~mm}$ \\
\hline Max & $1632.7 \mathrm{~mm}$ & $1564 \mathrm{~mm}$ \\
\hline Median & $1080 \mathrm{~mm}$ & $894.7 \mathrm{~mm}$ \\
\hline Std. Dev. & 337.2 & 330 \\
\hline CV\% & 32.09 & 35.64 \\
\hline Coefficient of skewness & -0.15 & 0.24 \\
\hline
\end{tabular}

Table 4: Computation of statistical parameters of Haridwar District.

And also provides information pertaining to the nature of trend. The analysis can be used as a tool to forecast the future behaviour of the trend. The method of least square fit for straight line has been used for trend analysis of the behaviour of annual rainfall. After trend analysis of data observed rainfall trend is going to increasing in zigzag pattern may be changing of climatic scenario in past years. The annual rainfall trend $1111 \mathrm{~mm}$ was observed maximum in year 1999 but declining condition in year 2018 was 1058.2 $\mathrm{mm}$ whereas same condition was observed lowest rainfall in south west rainfall trend $908 \mathrm{~mm}$ in year 1999 but maximum trend 917.1 $\mathrm{mm}$ observed in year 2018 . Figure 5 shows that the trend of annual rainfall, the $\mathrm{R}^{2}$ value -1.408 means that only ( -140.8 percent) negative variation and in south west rainfall, the $\mathrm{R}^{2}$ value 1.125 means that only ( -112 percent ) negative variation is observed in 20 years [15-20].

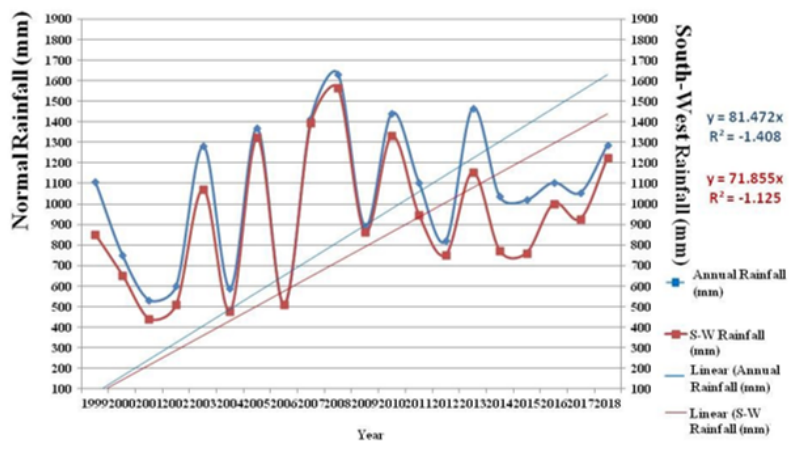

Figure 5: Annual and South-west Rainfall pattern (1999-2020).

\section{Forecasting of annual rainfall}

On the basis, the future forecast of rainfall for a period of ten years from 2019 to 2030 has been made (Table 5), which shows a negative trend for the coming years. In future, expected annual rainfall may be more in year 2030 observed $1024.9 \mathrm{~mm}$ in the district.

In the year 2019; expected rainfall may be $1055.5 \mathrm{~mm}$. On the basis, the future forecast of rainfall for a period of ten years from 2019 to 2030 has been made (Table), which shows a positive trend for the coming years. In future, expected South west rainfall l may be more in year 2030 observed $922.8 \mathrm{~mm}$ in the district. In the year 2019; expected rainfall may be $917.6 \mathrm{~mm}$. The trend analysis gives the scenario of current to expected future situation. So in view of future rainfall is going tobe decline. It will also affect the production of rabi and Kharif season crops. 


\begin{tabular}{|l|c|c|c|}
\hline \multicolumn{4}{|c|}{ Expected Future Rainfall (mm) trend } \\
\hline Sl. No. & Year & $\begin{array}{c}\text { Annual Rainfall } \\
\text { (mm) }\end{array}$ & $\begin{array}{c}\text { S-W Rainfall } \\
\text { (mm) }\end{array}$ \\
\hline 1 & 2019 & 1055.5 & 917.6 \\
\hline 2 & 2020 & 1052.7 & 918.0 \\
\hline 3 & 2021 & 1049.9 & 918.5 \\
\hline 4 & 2022 & 1047.1 & 919.0 \\
\hline 5 & 2023 & 1044.3 & 919.5 \\
\hline 6 & 2024 & 1041.6 & 920.0 \\
\hline 7 & 2025 & 1038.8 & 920.4 \\
\hline 8 & 2026 & 1036.0 & 920.9 \\
\hline 9 & 2027 & 1033.2 & 921.4 \\
\hline 10 & 2028 & 1030.5 & 921.9 \\
\hline 11 & 2029 & 1027.7 & 922.4 \\
\hline 12 & 2030 & 1024.9 & 922.8 \\
\hline
\end{tabular}

Table 5: Expected future Annual rainfall (mm) trend.

\section{Conclusion}

The average annual rainfall of region during 1999-2018 is 1051. mm. and south west monsoon rainfall $925.9 \mathrm{~mm}$ observed. The maximum annual rainfall recoded $1633 \mathrm{~mm}$ in year 2008 and lowest rainfall recoded $533 \mathrm{~mm}$ in year 2001. The maximum South west rainfall recoded $1564 \mathrm{~mm}$ in year 2008 and lowest rainfall recoded $439 \mathrm{~mm}$ in year 2001.The south west monsoon plays a vital role in rainfall for water cycle. It contributes the highest percentage of rainfall and kharif season crops are most of dependent on rainfall. The annual rainfall in year 2007 showing the highest positive rainfall anomaly (2.31) while the other years show rainfall below normal with 2009 Showing the lowest negative rainfall deviation (-2.03). and the South west (1999 to 2018) rainfall of Haridwar District in year 2018 showing the highest positive rainfall anomaly (2.15) while the other years show rainfall below normal with 2009 Showing the lowest negative rainfall deviation $(-2.05)$. The $R^{2}$ value -1.408 means that only -140.8 percent variations is observed in twenty years. The coefficient of skewness has been computed as - 0.15 for annual rainfall indicates a negative trend or going to decline pattern but in South west rainfall of coefficient of skewness has been computed as 0.24 for annual rainfall indicated a positive trend to increasing pattern

In future, expected annual rainfall may be less in year 2030observed $1025 \mathrm{~mm}$ in the District. The south west rainfall in the year 2030; expected rainfall may be $922.8 \mathrm{~mm}$. The trends are showing increasing trend pattern from year 2019 to 2030. The trend analysis gives the scenario of current to expected future situation. Water is a vital component for agricultural crops and in abnormal period crops are irrigated by available source viz. tube well, submersible, canal, irrigation channels and other sources. The statistical analysis of annual and south west rainfall of the study area will help to better water management. Today rainfall is not regular fashion so farmers are not more dependent much more on rainfall. The source of irrigation, mechanization and knowledge of current situation of weather and climate change related pattern and adaptation of technology is maintain to crops yield trend.

\section{Bibliography}

1. Crozier MJ. Management frameworks for landslide hazard and risk. In: Glade T, Anderson MG, Crozier MJ (eds) Landslide Hazard and Risk. Wiley, London (2005): 331-350.

2. Alatise MO and Ikumawoyi OB. "Evaluation of Drought from Rainfall Data for Lakoja. A Confluence of two Major Rivers". Electronic Journal of Polish Agricultural Universities 10.1 (2007).

3. Oladipo EO. "Comparative Performance Analysis of Three Meteorological Drought Indices". Journal of Climatology 6.5 (1985): 655-664.

4. Gogumalla P., et al. "Trend and Change Point Detection of Precipitation in Urbanizing Districts of Uttarakhand in India". Indian Journal of Science and Technology 7.10 (2014): 15731582.

5. Koshal AK and Kumar P. "Study of spatio-temporal analysis of annual rainfall variability in Uttar Pradesh". Journal of Plant Development Sciences 8.3 (2016): 97-110.

6. Shanu VK and Jahangeer. "Statistical distribution of rainfall in Uttarakhand, India”. Applied Water Science 7 (2017): 47654776.

7. G Pranuthi and S K Tripathi. "Assessing the climate change and its impact on rice yields of Haridwar district using PRECIS RCM data". Climatic Change, Springer 148.1 (2018): 265-278.

8. Rupali S Ahire and Nikam V. "Analysis of Changes in Rainfall Magnitude over Haridwar District, India". World Environmental and Water Resources Congress 2020.May 17-21. | Henderson, Nevada (2020).

9. https://forest.uk.gov.in/files/ForestWorksManual-FRI. pdf26.86percent 
10. Forest Survey of India. India State of Forest Report. Dehradun (2017).

11. http://cppgg.uk.gov.in/wp-content/uploads/2020/10/ Haridwar-Action-Plan-Draft.pdf

12. Hutchinson P. "Rainfall analysis of the Sahelian drought in the Gambia”. Journal Climatology 5 (1985): 665-672.

13. Ayoade JO. "Annual rainfall trends and periodicities in Nigeria". Nigerian Geographical Journal 16.2 (1973): 167-176.

14. Khalili A. "Country's water master plan publication- Updating report”. JAMAB Consultancy Company, Ministry of Power, Tehran, Iran (1999).

15. http://164.100.117.97/WriteReadData/userfiles / ISFR2019\%20Vol-II.pdf

16. http://www.frienvis.nic.in/Database/District-Wise-ForestCover-of-Uttarakhand_2476.aspx

17. http://www.apafri.org/publications/Forest $\% 20$ Hydrology\%20Extended\%20Abstract.pdf

18. Palmer WC. Meteorological Drought, Research Paper No.45, US Department of Commerce Weather Bureau, Washington DC (1965).

19. Smakhtin VU and Hughes DA. "Review, Automated Estimation and Analyses of Drought Indices in South Asia". Working Paper 83, Drought Series Paper 1 (2004).

20. Tallaksen LM and van Lanen HAJ. "Hydrological Drought Processes and Estimation Methods for Streamflow and Groundwater". Elsevier (2004).

\section{Assets from publication with us}

- Prompt Acknowledgement after receiving the article

- Thorough Double blinded peer review

- Rapid Publication

- Issue of Publication Certificate

- High visibility of your Published work

Website: www.actascientific.com/

Submit Article: www.actascientific.com/submission.php

Email us: editor@actascientific.com

Contact us: +919182824667

Citation: Avadhesh Kumar Koshal and Anamika Jain. "Study of Statistical Analysis of Indices Based Rainfall Trends in Haridwar District of Uttarakhand, India". Acta Scientific Agriculture 5.6 (2021): 02-10. 